\title{
PERLINDUNGAN SAKSI DAN KORBAN DALAM PROSES PENEGAKAN HUKUM PIDANA
}

\author{
Yudi Krismen
}

Abstrak

Berbicara tentang saksi dan korban, kita tidak bisa terlepas daripada proses pidana. Dalam ketentuan Pasal 184 ayat (1) huruf a Kuhap saksi diposisikan sebagai "alat bukti" yang utama dalam perkara pidana. Sehingga konsekwensinya, dalam setiap proses penegakan hukum apabila saksi tidak memenuhi panggilan yang sah dari penyidik, penuntut hingga pemeriksaan pengadilan, maka penyidik, penuntut bisa melakukan upaya paksa dengan menjemput paksa saksi. Karena, proses pidana masih terikat dengan doktrin yang di introdusir KUHAP, dimana saksi dalam Rumusan KUHAP menitikberatkan pada "nilai pembuktian”. Namun, dengan disahkannya Undang-undang Nomor 13 Tahun 2006 tentang Perlindungan Saksi dan Korban, diharapkan dapat mengatasi persoalan-persoalan hukum terhadap saksi dan korban secara berkepanjangan dalam proses pidana.

Kata Kunci: Saksi, Korban dan Proses Penyidikan Tindak Pidana

\section{ABSTRAK}

Speaking about victims and witnesses, we can not be separated rather than criminal proceedings. In the provision of Article 184 paragraph (1) letter a witnesses KUHAP positioned as "evidence" that major in criminal matters. So consequently, in every process of law enforcement if the witness does not meet the legitimate calls from investigators, prosecutors until trial, the investigator, the prosecutor can conduct a forced effort to pick up the forced witnesses. Because, criminal proceedings are still bound by doctrine in introdusir Criminal Procedure Code, Criminal Procedure Code where the witness in the formulation of concentrating on "no probative value". However, with the enactment of Law No. 13 of 2006 on Protection of Witnesses and Victims, is expected to address issues of law against prolonged witnesses and victims in criminal proceedings.

Keywords: Witnesses, Victims and Crime Investigation Process

\section{PENDAHULUAN}

Saksi adalah salah satu alat bukti yang terdapat dalam rumusan pasal 184 Kuhap. Istilah unus testis nullus testis yang artinya satu saksi bukanlah saksi seakan-akan mengungkapkan bahwa begitu besarnya peranan saksi dalam proses penegakan hukum pidana. Pasal 184 ayat (1) huruf a Kuhap, telah menempatkan pentingnya kedudukan saksi sebagai alat bukti yang utama dalam perkara pidana. Karena, berhasilnya sebuah proses peradilan sangat tergantung pada pengumpulan alat bukti yang berhasil ditemukan oleh penyidik.

Berbicara tentang saksi, artinya terkait dengan pembuktian perkara. Karena, keterangan saksi dalam system peradilan pidana Indonesia sangat memegang peranan penting dalam pembuktian, karena keterangan saksi dapat membantu untuk membuktikan apakah sebuah perbuatan pidana sudah terjadi, dan apakah perbuatan itu dapat dipidana dengan terpenuhinya unsur-unsur pasal yang disangkakan atau didakwakan terhadap sipetindak/pelaku tindak pidana, terutama jika dalam hal tersangka/terdakwa melakukan penyangkalan terhadap sangkaan atau dakwaan penuntut umum dalam persidangan.

Pentingnya keterangan saksi korban dalam proses penyidikan perkara sampai dengan proses pemeriksaan di persidangan pengadilan. Karena, system hukum kita masih menganut system hukum eropa continental dengan mengacu kepada asas legalitas dengan kepastian hukum, maka suatu kewajiban hukum bagi saksi untuk hadir dan menghadir saksi pada setiap proses penegakan hukum, sehingga bila seseorang saksi tidak memenuhi panggilan yang sah dari penyidik, penuntut hingga pemeriksaan pengadilan, maka dengan segala kewenangan yang ada padanya penyidik, penuntut bisa melakukan upaya paksa dengan menjemput paksa saksi. Begitu juga dalam proses persidangan jika saksi tidak hadir sesuai dengan surat panggilan yang sah tanpa adanya alasan yang patut dan wajar, maka Ketua Majelis Hakim dapat memerintahkan Jaksa Penuntut 
Umum agar saksi tersebut dihadapkan secara paksa untuk hadir memberikan keterangannya didepan persidangan, sebagaimana dimaksud dalam pasal ayat (2) Kuhap. Surastini Fitrianingsih $^{1}$ menyatakan bahwa, ada resikoresiko tertentu yang dapat menimpa seseorang saksi antara lain:

1). Bagi saksi yang awam hukum, memberikan keterangan bukanlah suatu hal yang mudah;

2). Bila keterangan yang diberikan ternyata tidak benar, ada ancaman pidana baginya, karena telah dianggap memberikan keterangan palsu;

3). Keterangan yang diberikan akan memungkinkan dirinya mendapatkan ancaman, terror, intimidasi dari pihak yang merasa dirugikan;

1) memberikan keterangan seakan membuang waktu saja;

2) aparat penegak hukum tidak jarang memperlakukan saksi seperti seorang tersangka ataupun terdakwa.

Dengan segala resiko yang dihadapi oleh saksi dan korban tersebut diatas, sehingga saksi dan korban dalam pemenuhan panggilan tersebut hanyalah dianggap sebagai pemenuhan kewajiban hukum saja bagi masyarakat yang mengetahui terjadinya tindak pidana atau masyarakat yang menjadi korban dalam suatu tindak pidana yang sudah terjadi pada dirinya. Sehingga saksi ataupun korban akan menjadi enggan untuk melaporkan tentang sudah terjadinya suatu tindak pidana, karena saksi tidak mau repot dan menghabiskan waktu untuk memberikan keterangannya dalam setiap tingkat proses penegakan hukum itu. walaupun hak-hak saksi sudah diatur dengan jelas dalam UU Perlindungan saksi dan Korban.

\section{RUMUSAN MASALAH}

Dilandasi latar belakang masalah tersebut di atas serta agar tidak terjadi kerancuandalam pembahasan makalah nantinya, maka penulis membatasi permasalahan dengan rumusannya yaitu:

1 Surastini Fitriasih, "Perlindungan Saksi Dan Korban Sebagai Sarana Menuju Proses Peradilan (Pidana) Yang Jujur Dan Adil", http/www.antikorupsi.org/mod=tema\&op=viewart icle\&artid $=53$
1. Bagaimanakah perlindungan saksi dan korban dalam proses penyidikan tindak pidana ?

2. Apakah Kendala-Kendala dalam pemberian keterangan oleh saksi dan korban dalam proses penyidikan perkara?

\section{PEMBAHASAN}

\section{Pengertian Viktimologi}

Penanggulangan kejahatan tidak hanya terfokus pada timbulnya kejahatan atau metode yang digunakan dalam penyelesaian para pelaku kejahatan. Ada, hal lain yang tidak kalah penting lagi yaitu: masalah korban kejahatan, dimana dalam keadaan tertentu dapat memicu terjadinya kajahatan.

Berbicara tentang korban berarti kita berbicara tentang viktimologi. kata Victimologi berasal dari bahasa latin "Victima" yang berarti korban dan "Logos" yang berarti ilmu. Secara terminologi Victimologi berarti suatu studi yang mempelajari tentang korban, penyebab timbulnya korban dan akibat-akibat penimbulan korban yang merupakan masalah manusia sebagai kenyataan sosial, korban dalam lingkup Victimologi mempunyai arti yang luas ${ }^{2}$. Menurut Kamus Chrime Dictionary bahwa victim adalah "orang yang telah medapat penderitaan fisik atau penderitaan mental, kerugian harta benda atau mengakibatkan mati atas perbuatan atau usaha pelanggaran ringan dilakukan oleh pelaku tindak pidana dan lainnya. Dalam kamus ilmu pengetahuan sosial disebutkan bahwa victimologi adalah studi tentang tingkah laku victim sebagai salah satu penentu terjadinya kejahatan ${ }^{3}$.

Arif Gosita memberikan pengertian victimologi adalah mereka yang menderita jasmaniah dan rohaniah sebagai akibat tindakan orang lain yang mencari pemenuhan diri sendiri dalam konteks kerakusan individu dalam memperoleh apa yang diinginkan secara tidak baik dan sangat melanggar ataupun bertentangan dengan kepentingan dan hak asasi yang menderita, sebab dan kenyataan sosial yang

\footnotetext{
${ }^{2}$ sebab tidak hanya terbatas pada individu yang nyata menderita kerugian, tapi juga kelompok, korporasi, swasta maupun pemerintah

${ }^{3}$ Hugo Reading, Kamus IImu-ilmu social, Rajawali, Jakarta, 1986, hlm. 457.
} 
dapat disebut sebagai korban tidak hanya korban perbuatan pidana (kejahatan) saja tetapi dapat korban bencana alam, korban kebijakan pemerintah dan lain-lain ${ }^{4}$.

Sedangkan, Korban dalam pengertian yuridis yang termaktub dalam perundangundangan No.13 Tahun 2006 tentang perlindungan saksi dan korban adalah seseorang yang mengalami penderitaan fisik, mental, dan/atau kerugian ekonomi yang diakibatkan oleh suatu tindak pidana". Menurut Peraturan pemerintah No.2 Tahun 2002 tentang tata cara perlindungan terhadap saksi-saksi dalam pelanggaran HAM yang berat, Korban adalah orang perseorangan atau kelompok orang yang mengalami penderitaan sebagai akibat pelanggaran hak asasi manusia yang berat yang memerlukan perlindungan fisik dan mental dari ancaman gangguan, terror, dan kekerasan pihak manapun.

Dalam Undang-undang No. 23 tahun 2004 tentang penghapusan kekerasan dalam rumah tangga, Korban adalah "orang yang mengalami kekerasan atau ancaman kekerasan dalam ruang lingkup rumah tangga". Undangundang No.27 Tahun 2004 tentang komisi kebenaran dan rekonsiliasi, Korban adalah orang perseorangan atau kelompok orang yang mengalami penderitaan, baik fisik, mental maupun emosional, kerugian ekonomi atau mengalami pengabaian pengurangan atau perampasan hak-hak dasarnya sebagai akibat pelanggaran hak asasi manusia yang berat termasuk korban atau ahli warisnya.

\section{Ruang Lingkup Viktimologi}

Viktimologi adalah ilmu tentang korban kejahatan, yang meneliti topiktopik tentang korban, seperti peranan korban pada terjadinya tindak pidana, hubungan antara pelaku dengan korban, rentannya posisi korban dan peranan korban dalam system peradilan pidana. Menurut JE Sahetapy, ruang lingkup viktimologi meliputi bagaimana seseorang (dapat) menjadi korban yang ditentukan oleh suatu

victimity yang tidak selalu berhubungan den gan masalah kejahatan, termasuk pola korban

\footnotetext{
${ }^{4}$ Arif Gosita, Masalah Korban Kejahatan, Akademika Pressindo, Jakarta, 1985, hlm. 54
}

kecelakaan, dan bencana alam selain dari korban kejahatan dan penyalahgunaan kekuasaan.

\section{Menurut}

Arief

Gosita,

Objek studi atau ruang lingkup viktimologi a dalah sebagai berikut ${ }^{5}$ :

a. Berbagai macam viktimisasi kriminal atau kriminalistik.

b. Teori-teori etiologi viktimisasi kriminal.

c. Para peserta terlibat dalam terjadinya atau ek sistensi suatu viktimisasi kriminal atau kriminalistik, seperti para korban, pelaku, pengamat, pembuat undangundang, polisi, jaksa, hakim, pengacara dan sebagainya.

d. Reaksi terhadap suatu viktimisasi kriminal.

Respons terhadap suatu viktimisasi kri minal argumentasi kegiatankegiatan penyelesaian suatu viktimisasi at au viktimologi, usahausaha prevensi, refresi, tindak lanjut (gant i kerugian), dan pembuatan peraturan hukum yang berkaitan.

f. Faktor-faktor viktimogen/ kriminogen.

Ruang lingkup atau objek studi vikti mologi dan kriminologi dapat dikatakan sama, yang berbeda adalah titik tolak pangkal, pengamatannya dalam memahami suatu viktimisasi kriminal, yaitu viktimologi dari sudut pihak korban sedangkan kriminologi dari sudut pihak pelaku. Masing-masing merupakan komponen-komponen suatu interaksi (mutlak) yang hasil interaksinya adalah suatu viktimisasi kriminal atau kriminalitas. ${ }^{6}$

Suatu viktimisasi antara lain dapat $d$ irumuskan sebagai suatu penimbunan penderitaan (mental, fisik, sosial, ekonomi, moral) pada pihak tertentu dan dari kepentingan tertentu. Menurut J.E. Sahetapy, viktimisasi adalah penderitaan, baik secara fisik maupun psikis atau mental berkaitan de ngan perbuatan pihak lain ${ }^{7}$.

Pandangan J.E. Sahetapy mengenai paradigma viktimisasi yang meliputi ${ }^{8}$ :

\begin{tabular}{lll}
\hline & ${ }^{5}$ Ibid. \\
& ${ }^{6}$ Ibid. Hal.39 \\
& ${ }^{7}$ J.E. Sahetapy, SH, Teori Kriminologi \\
Suatu Pengantar, Citra Aditya Bakti, Bandung, \\
$1992 \quad{ }^{8}$ Muhadar, Viktimisasi Kejahatan \\
Pertanahan, hlm 22
\end{tabular}


a. Viktimisasi politik, dapat dimasukkan as pek penyalahgunaan kekuasaan, perkosaan hak-hak asasi manusia, campur tangan angkatan bersenjata diluar fungsinya, terorisme, intervensi, dan peperangan lokal atau dalam skala internasional;

b. Viktimisasi ekonomi, terutama yang terjadi karena ada kolusi antara pemerintah dan konglomerat, produksi barang-barang tidak bermutu atau yang merusak kesehatan, termasuk aspek lingkungan hidup;

c. Viktimisasi keluarga, seperti perkosaan, pen yiksaan terhadap anak dan istri dan menelantarkan kaum manus ia lanjut atau orang tuanya sendiri;

d. Viktimisasi media, dalam hal ini dapat disebut penyalahgunaan obat bius, alkoholisme, malpraktek di bidang kedokteran dan lain-lain;

e. Viktimisasi yuridis, dimensi ini cukup luas, baik yang menyangkut aspek perdilan dan Lapas maupun yang menyangkut dimensi diskriminasi perundang-undangan, termasuk menerapkan kekuasan dan stigmatisasi kendatipun sudah diselesaikan aspek peradilannya;

\section{Sejarah Viktimologi}

Perkembangan Victimologi tidak terlepas dari pemikir terdahulu yaitu hans Von Henting seorang ahli kriminologi pada tahun 1941 menulis sebuah makalah yang berjudul "Remark on the interaction of perpetrator and victim." dan Tujuh Tahun kemudian beliau menerbitkan buku yang berjudul The Criminal and his victim yang menyatakan bahwa korban mempunyai peranan yang menentukan dalam timbulnya kejahatan. Mendelsohn pada tahun 1947 dimana pemikirannya sangat mempengaruhi setiap fase perkembangan Victimologi. Pada Tahun 1947 atau setahun sebelum buku von Hentig terbit, Mendelsohn menulis sebuah makalah dengan judul "New bio-psycho-sosial horizons: Victimology." Pada saat inilah istilah victimology pertama kali digunakan. Dimana perkembangannya dapat dibagi dalam tiga fase yaitu :

1. fase Pertama Victimologi hanya mempelajari korban kejahatan saja (Penal or Special Victimology).

2. fase kedua Victimologi tidak hanya mengkaji masalah korban kejahatan tetapi juga meliputi korban kecelakaan (General Victimology).
3. fase ketiga Victimologi lebih luas lagi yaitu mengkaji permasalahan korban penyalahgunaan kekuasaan dan hak-hak asasi manusia (New Victimology). ${ }^{9}$

Dari pengertian diatas, nampak jelas yang menjadi objek kajian Victimologi diantaranya adalah pihak-pihak mana saja yang terlibat atau mempengaruhi terjadinya suatu Victimisasi, faktor-faktor respon, serta upaya penanggulangan dan sebagainya.

Setelah itu para sarjana-sarjana lain mulai melakukan studi tentang hubungan psikologis antara penjahat dengan korban, bersama H. Mainheim, Schafser, dan Fiseler. Setelah itu pada Tahun 1949 W.H. Nagel juga melakukan pengamatan mengenai viktimologi yang dituangkan dalam tulisannya dengan judul “de Criminaliteit van Oss, Gronigen.", dan pada Tahun 1959 P. Cornil dalam penelitiannya menyimpulkan bahwa si korban patut mendapatkan perhatian yang lebih besar dari kriminologi dan viktimologi. sehinga pada Tahun 1977 didirikanlah World Society ofVictimology. World Society ofVictimology (WSV) dipelopori oleh Schneider dan Drapkin. Perubahan terbesar dari perkembangan pembentukan prinsip-prinsip dasar tentang perlindungan korban terwujud pada saat diadakannya kongres di Milan, pada tanggal 26 Agustus 1985 yang menghasilkan beberapa prinsip dasar tentang korban kejahatan dan penyalahgunaan kekuasaan yang selanjutnya diadopsi oleh Perserikatan BangsaBansa pada tanggal 11 Desember 1985 dalam suatu deklarasi yang dinamakan Decleration of Basic Principle of Justice for Victims of Crime and Abuse Power.

\section{Perlindungan Saksi dan Korban Kejahatan}

Jaya $^{10}, \begin{gathered}\text { Menurut } \\ \text { bahwa }\end{gathered} \begin{gathered}\text { Nyoman Serikat Putra } \\ \text { perhatian masyarakat }\end{gathered}$ internasional terhadap korban kejahatan nampak dengan diadakannya kongres seperti di Milan tanggal 26 Agustus sampai tanggal 6 September 1985 yaitu United Nation Congress on the Prevention of Crime andthe Treatment of Offenders ke VII dengan tema "Pencegahan

\begin{tabular}{l}
\hline${ }^{9}$ Didik M. Arif Mansur, Urgensi \\
Perlindungan Korban Kejahatan, Hal. 35 \\
Nyoman Serikat Putra Jaya, \\
Sistem Peradilan Pidana (Criminal Justice \\
Sistem), (Bahan KuliahProgram Magister \\
Ilmu Hukum Universitas Diponegoro \\
,Semarang: 2006 ), hal. 5.
\end{tabular}


Kejahatan, untuk Kebebasan, Keadilan, Kedamaian dan Pembangunan". Salah satu topik yang dibicarakan secara mendalam adalah masalah korban kejahatan.

Pada kesempatan itu dihasilkan sebuah draft Deklarasi yang di dalamnya memuat rekomendasi agar korban kejahatan diberi hak "to be present and to be heardat all critical stages of judicial proceeding". Selanjutnya di jelaskan bahwa, pada tahun 1963 di New Zealand juga ada peraturan yang memberikan landasan bahwa orang yang menjadi korban dari tindak pidana kekerasan dapat memperoleh ganti rugi, ialah "CriminalInjuries Compensation Act". Di negara bagian Ontario misalnya ada "OntarioCriminal Injuries Compensation Scheme". Di negeri Belanda diundangkan "Wet voorlopige schandenfons geweld-misdrijven"11. Menteri Kehakiman Belanda memberi alasan mengapa masyarakat sebagai keseluruhan mempunyai tanggung jawab atas korban dari kejahatan kekerasan. Tanggung jawab itu didasarkan atas tiga hal ${ }^{12}$;

Pertama, tanggung jawab itu dihubungkan dengan keadaan bahwa penguasa menyatakan beberapa perbuatan tertentu sebagai pelanggaran berat dan penyerangan terhadap ketertiban hukum yang berat. Sebagai kelanjutan dari pengancaman dengan pidana terhadap perbuatan-perbuatan itu, maka dapat dipikirkan adanya suatu tugas dari penguasa untuk meringankan atau menghilangkan akibat perbuatan itu.

Kedua, yang bersifat lebih filsafati, masyarakat dapat dipandang sebagai jaringan halus dari perbuatan manusia, sehingga setiap orang dalam arti manusiawi pada umumnya "ikut bersalah" atas apa yang akhirya menjelma sebagai kesalahan seorang oknum yang melakukan tindak pidana. Singkatnya di sini ada solidaritas dengan orang yang menjadi korban kejahatan.

Ketiga, pertimbangan yang penting untuk politik hukum; peraturan itu dipandang mempunyai pengaruh mendamaikan atau menyelesaikan konflik ("conflictoplossing") : apabila ada penggarapan khusus demi para korban dari tindak pidana maka iklim socialpsikologis menjadi baik untuk memperlakukan

${ }_{12}^{11}$ bid, hal. 54

12 Nyoman Serikat Putra Jaya, Opcit, hal. 54. dalam Sudarto, 1986, hal. 189-190 si pembuat dengan cara yang paling meguntungkan dari sudut prevensi sosial.

Pengertian saksi secara tegas dinyatakan dalam lingkup perkara pidana. Dimana rumusannya menggunakan konsep sebagaimana diatur dalam Kitab Undangundang Hukum Acara Pidana (KUHAP). Perbedaan rumusan saksi dalam KUHAP dengan UU Perlindungan Saksi dan Korban terdapat pada status saksi, dimana dalam UU Perlindungan Saksi dan Korban sudah dimulai di tahap penyelidikan sedangkan dalam KUHAP status saksi dimulai dari tahap penyidikan. Untuk itu pengertian saksi dalam UU Perlindungan Saksi dan Korban sudah sedikit lebih maju, karena berupaya mencoba memasukkan atau (memperluas) perlindungan terhadap orang-orang yang membantu dalam upaya penyelidikan pidana yang masih berstatus pelapor atau pengadu. Walaupun pun tidak secara tegas dinyatakan bahwa pelapor juga dilindungi, tapi para perumus berkeyakinan bahwa pelapor sudah tercakup dalam wilayah penyelidikan.

Namun perlindungan terhadap status saksi dalam konteks penyelidikan ini pun masih terbatas dan kurang memadai karena terbentur pada doktrin yang di introdusir KUHAP, dimana saksinya dalam Rumusan KUHAP menitikberatkan pada "nilai pembuktian" berbeda dengan orang-orang yang dapat dilindungi oleh Lembaga Perlindungan Saksi. jika diperhatikan lebih rinci elemen pasal KUHAP, maka seorang saksi haruslah ; (1) melihat, mendengar suatu tindak pidana, dan/atau (2) mengalami suatu tindak pidana. Sehingga, saksi yang masuk dalam UU Nomor 13 Tahun 2006 tentang Perlindungan Saksi dan Korban sangatlah terbatas karena harus memenuhi salah satu syarat alternatif diatas, syarat untuk nomor 1 haruslah terpenuhi duaduanya (melihat dan mendengar) karena setelah "kata" melihat diberi tanda koma, (bukan atau). Berbeda lagi dengan perlindungan terhadap Pelapor sendiri telah lebih awal diatur dalam pasal 31 UU No. 31 Tahun 1999 tentang Pemberantasan Tindak Pidana Korupsi yang menjelaskan bahwa pelapor tidak dapat diajukan dalam sidang pengadilan melainkan harus dilindungi identitas dan alamatnya.

Sedangkan, di beberapa Negara Asia, pengadilannya sudah memberikan keterangan saksi lebih menitik beratkan, pada perlindungan saksi dan korban. Sangat diutamakan dalam perkara korupsi dan penyiksaan oleh polisi dan 
pelanggaran Hak Asasi Manusia lainnya. Di Indonesia kehadiran Undang-undang perlindungan saksi, merupakan suatu hal yang membahagiakan bagi saksi, mengingat masih banyaknya keluhan masyarakat mengenai perlu dan pentingnya perlindungan saksi. Namun yang menjadi persoalan saat ini adalah kehadiran undang-undang ini ternyata terkesan hanya isapan jempol belaka, hal ini dapat dibuktikan bahwa sejak lahirnya Undangundang Nomor 13 Tahun 2006 tentang Perlindungan Saksi dan Korban tanggal 11 Agustus 2006, namun hingga saat ini belum mampu menjawab persoalan masyarakat karena belum terbentuknya komponen hukum lainnya kaitannya dengan perlindungan saksi. Sehingga, Perlindungan saksi dalam proses peradilan pidana adalah merupakan fenomena hukum acara pidana Indonesia, dimana dalam penegakannya akan selalu bersinggungan dengan para penegak hukum itu sendiri.

\section{Implementasi Perlindungan saksi dan Korban}

Dalam pelaksanaan perlindungan saksi dan korban tidak terlepas dari beberapa persoalan, yakni ; penegakkan hukum perlindungan saksi dan korban, kapan dilakukan perlindungan saksi dan korban, bentuk-bentuk perlindungan saksi dan korban dan tata cara perlindungan saksi dan korban dalam proses peradilan pidana.

\section{a) Penegakan Hukum dan Perlindungan Saksi dan korban}

Dalam pasal 1 ayat 20 Kuhap, yang dimaksud dengan saksi adalah orang yang dapat memberikan keterangan guna kepentingan penyidikan, penuntutan, dan peradilan tentang suatu perkara pidana yang ia dengar sendiri, ia lihat sendiri dan ia alami sendiri. Dalam pasal tersebut dijelaskan bahwa saksi adalah orang yang melihat, mendengar serta mengalami kejadian pidana. Dapat ditegaskan bahwa, jika saksi mengalami sendiri kejadiannya secara langsung, maka posisi saksi bisa sekaligus menjadi korban kejahatan. Selanjutnya dalam pasal 1 ayat 27 Kuhap, menjelaskan yang dimaksud dengan keterangan saksi adalah salah satu alat bukti dalam perkara pidana yang berupa keterangan dari saksi mengenai suatu peristiwa pidana yang ia dengan sendiri, ia lihat sendiri dan ia alami sendiri dengan menyebut alasan dari pengetahuannnya itu.
Namun demikian ada beberapa syarat lain disebutkan dalam UU No. 8 Tahun 1981 tentang Kuhap, agar keterangan saksi dapat dijadikan sebagai alat bukti, yaitu:

1) keterangan saksi harus diberikan di sidang pengadilan (pasal 185 ayat (1) Kuhap);

2) sebelum memberikan keterangan saksi harus mengucapkan sumpah menurut tata cara agama yang dianutnya untuk memberikan keterangan yang benar dan tidak lain dari pada yang sebenarnya (pasal 160 ayat 3 Kuhap).

Keterangan saksi adalah salah satu alat bukti yang sah dalam proses peradilan pidana dimana keterangan saksi dan/atau korban yang mendengar, melihat, atau mengalami sendiri terjadinya suatu tindak pidana dalam upaya mencari dan menemukan kejelasan tentang tindak pidana yang dilakukan oleh pelaku tindak pidana. Penegak hukum dalam mencari dan menemukan kejelasan tentang tindak pidana yang dilakukan oleh pelaku tindak pidana sering mengalami kesulitan karena tidak dapat menghadirkan saksi dan/atau korban disebabkan adanya ancaman, baik fisik maupun psikis dari pihak tertentu.

Dalam rangka perlindungan saksi dan korban, khususnya perlindungan hukum bagi saksi itu sendiri, saat ini telah diatur oleh Undang-undang Nomor 13 Tahun 2006 tentang Perlindungan Saksi dan Korban. Sebuah Undang-undang Perlindungan Saksi dan Korban yang berlaku efektif, seperti pelanggaran hak asasi manusia, adalah satu kesatuan integral dalam rangka menjaga berfungsinya sistem peradilan pidana terpadu. Setelah di sahkan Undang-undang Perlindungan Saksi dan Korban, diharapkan dapat menyelesaikan permasalahan hukum yang berkepanjangan seperti sulitnya memberantas korupsi, kekerasan dalam rumah tangga, kekerasan terhadap perempuan dan belum lagi tentang perlindungan hukum yang hanya mampu menyentuh bagi kalangan konglomerat, pejabat, dan lain sebagainya.

Sehingga diperlukan perlindungan hukum sebagai payung hukum bagi para saksi dan korban di masa mendatang. Dimana, Undang-undang Perlindungan Saksi dan Korban bisa menjawab persoalan di atas. Perlindungan terhadap saksi dan korban wajib diberikan bila menginginkan proses hukum berjalan benar dan berkeadilan. Dengan memperhatikan adanya fakta menunjukkan, banyaknya kasus-kasus pidana maupun pelanggaran Hak Asasi Manusia yang tidak terungkap dan tidak terselesaikan, disebabkan adanya ancaman baik fisik atau 
psikis maupun upaya kriminalisasi terhadap saksi dan korban ataupun keluarganya yang membuat masyarakat takut memberi kesaksian kepada penegak hukum.

\section{b) Bentuk-bentuk Perlindungan Saksi}

Menurut Yenti Garnasih ${ }^{13}$ ada dua model perlindungan saksi yang bisa diberikan kepada saksi dan korban yaitu:

\section{(1) Procedural rights model}

Model ini memungkinkan korban berperan aktif dalam proses peradilan tindak pidana. Dimana "Korban diberikan akses yang luas untuk meminta segera dilakukan penuntutan, korban juga berhak meminta dihadirkan atau didengarkan keterangannya dalam setiap persidangan dimana kepentingan korban terkait di dalamnya. Termasuk pemberitahuan kepada korban disaat pelaku tindak pidana dibebaskan. Model ini memerlukan biaya yang cukup besar dengan besarnya keterlibatan korban dalam proses peradilan, sehingga biaya administrasi peradilanpun makin besar karena proses persidangan bisa lama dan tidak sederhana.

\section{(2) The service model.}

Model ini menentukan standar baku tentang pelayanan terhadap korban yang dilakukan oleh polisi, jaksa dan hakim. Misalnya pelayanan kesehatan, pendampingan, pemberian kompensasi dan ganti rugi serta restitusi. Banyaknya pelayanan yang harus diberikan kepada saksi dan korban menyebabkan efisiensi pekerjaan dari penegak hukum tidak tercapai. Efek lain juga sulit memantau apakah pelayanan itu benarbenar diterima saksi dan korban.

Model yang bisa diterapkan di Indonesia adalah kombinasi keduanya, karena di Negara Indonesia paling susah adalah dalam hal koordinasi. Oleh karena itu, kedua model itu harus disesuaikan dengan keadaan Indonesia, harus diukur sejauh mana saksi dan korban bisa terlibat dalam proses peradilan. Begitu pula tentang pemenuhan hak yang dapat diberikan kepada saksi dan korban.

\footnotetext{
13“UU No. 13 Tahun 2006 LPSK tidak mengatur perlindungan terhadap saksi dan korban secara spesifik. Sangat tergantung pada anggota Lembaga Perlindungan Saksi dan Korban", http://hukumonline.com/detail.asp?id=1776 $7 \& \mathrm{cl}=$ Berita $-49 \mathrm{k}$
}

Sedangkan, Undang-undang Nomor 13 Tahun 2006 tentang Perlindungan Saksi dan Korban, mengatur tentang perlindungan saksi adalah sebagai berikut :

a) Perlindungan atas keamanan pribadi, keluarga dan harta bendanya serta bebas dari ancaman yang berkaitan dengan kesaksian yang akan, sedang atau telah diberikan.

b) Ikut serta dalam proses memilih dan menentukan bentuk perlindungan serta dukungan keamanan

c) Memberikan keterangan tanpa tekanan d) Mendapat penerjemah

e) Bebas dari pertanyaan yang menjerat

f) Mendapatkan informasi mengenai perkembangan kasusnya

g) Mendapatkan informasi mengenai putusan pengadilan

h) Diberitahu ketika terpidana dibebaskan

i) Mendapatkan identitas baru

j) Mendapatkan tempat kediaman baru

k) Penggantian biaya transportasi

1) Mendapatkan penasihat hukum

m) Memperoleh bantuan biaya hidup sementara sampai batas waktu perlindungan berakhir.

n) Perlindungan yang diberikan Undangundang Perlindungan Saksi dan Korban, terhadap saksi dan korban diatur dalam Pasal 5, bahwa hak tersebut diberikan kepada saksi dan/atau korban tindak pidana dalam kasus-kasus tertentu sesuai dengan keputusan Lembaga Perlindungan Saksi dan Korban. Sedangkan Korban dalam pelanggaran hak asasi manusia yang berat, diberikan hak untuk mendapatkan:

- bantuan medis;

- bantuan rehabilitasi psiko-sosial.

Korban melalui Lembaga Perlindungan Saksi dan Korban berhak mengajukan ke pengadilan berupa:

a) hak atas kompensasi dalam kasus pelanggaran hak asasi manusia yang berat;

b) hak atas restitusi atau ganti kerugian yang menjadi tanggung jawab pelaku tindak pidana.

Keputusan mengenai kompensasi dan restitusi diberikan oleh pengadilan, dan ketentuan lebih lanjut mengenai pemberian kompensasi dan restitusi diatur dengan Peraturan Pemerintah. Perlindungan dan hak saksi dan korban diberikan sejak tahap 
penyelidikan dimulai dan berakhir. Saksi dan/atau korban yang merasa dirinya berada dalam ancaman yang sangat besar, atas persetujuan hakim dapat memberikan kesaksian tanpa hadir langsung di pengadilan tempat perkara tersebut sedang diperiksa.

Saksi dan/atau korban dapat memberikan kesaksiannya secara tertulis yang disampaikan di hadapan pejabat yang berwenang dan membubuhkan tanda tangannya Pada berita acara yang memuat tentang kesaksian tersebut. Saksi dan/atau korban dapat pula didengar kesaksiannya secara langsung melalui sarana elektronik dengan didampingi oleh pejabat yang berwenang. Saksi, korban, dan pelapor tidak dapat dituntut secara hukum baik pidana maupun perdata atas laporan, kesaksian yang akan, sedang, atau telah diberikannya.

Seorang saksi yang juga tersangka dalam kasus yang sama tidak dapat dibebaskan dari tuntutan pidana apabila ia ternyata terbukti secara sah dan meyakinkan bersalah, tetapi kesaksiannya dapat dijadikan pertimbangan hakim dalam meringankan pidana yang akan dijatuhkan. Ketentuan tersebut tidak berlaku terhadap saksi, korban, dan pelapor yang memberikan keterangan tidak dengan itikad baik.

\section{c) Syarat dan Tata Cara Perlindungan Saksi}

Menurut Pasal 28 Undang-undang Perlindungan Saksi dan Korban, bahwa perjanjian perlindungan Lembaga Perlindungan Saksi dan Korban terhadap saksi dan/atau korban tindak pidana diberikan perlindungan dengan mempertimbangkan syarat sebagai berikut:

1). Sifat pentingnya keterangan saksi dan/atau korban;

2).Tingkat ancaman yang membahayakan saksi dan/atau korban;

3) hasil analisis tim medis atau psikolog terhadap saksi dan/atau korban;

4). Rekam jejak kejahatan yang pernah dilakukan oleh saksi dan/atau korban.

Dalam Pasal 29 Undang-undang Perlindungan Saksi dan Korban menyatakan bahwa Tata cara memperoleh perlindungan sebagai berikut: a. Saksi dan/atau korban yang bersangkutan, baik atas inisiatif sendiri maupun atas permintaan pejabat yang berwenang, mengajukan permohonan secara tertulis kepada Lembaga Perlindungan Saksi dan Korban;

b. Lembaga Perlindungan Saksi dan Korban segera melakukan pemeriksaan terhadap permohonan;

c. Keputusan Lembaga Perlindungan Saksi dan Korban diberikan secara tertulis paling lambat 7 (tujuh) hari sejak permohonan perlindungan diajukan ${ }^{14}$.

Dalam surat pernyataan kesediaan mengikuti syarat dan ketentuan perlindungan saksi dan korban yang diajukan kepada Lembaga Perlindungan Saksi dan Korban, saksi sebagai pembuat pernyataan, harus memuat:

1) kesediaan saksi dan/atau korban untuk memberikan kesaksian dalam proses peradilan;

2) kesediaan saksi dan/atau korban untuk menaati aturan yang berkenaan dengan keselamatannya;

3) kesediaan saksi dan/atau korban untuk tidak berhubungan dengan cara apa pun dengan orang lain selain atas persetujuan Lembaga Perlindungan Saksi dan Korban, selama ia berada dalam perlindungan Lembaga Perlindungan Saksi dan Korban ;

4) kewajiban saksi dan/atau korban untuk tidak memberitahukan kepada siapa pun mengenai keberadaannya di bawah perlindungan Lembaga Perlindungan Saksi dan Korban ; dan

5) hal-hal lain yang dianggap perlu oleh Lembaga Perlindungan Saksi dan Korban .

Perlindungan atas keamanan saksi dan/atau korban hanya dapat diberhentikan berdasarkan alasan-alasan seperti yang tercantum dalam Pasal 32 yaitu:

\footnotetext{
${ }^{14}$ Bagi saksi dan/atau korban yang menghendaki perlindungan dari Lembaga Perlindungan Saksi dan Korban, saksi dan/atau korban baik atas inisiatif sendiri maupun atas permintaan pejabat yang berwenang, mengajukan permohonan secara tertulis kepada Lembaga Perlindungan Saksi dan Korban. Undang-undang Perlindungan Saksi dan Korban lebih kongkrit menegaskan bahwa dalam hal Lembaga Perlindungan Saksi dan Korban menerima permohonan saksi dan/atau korban, saksi dan/atau korban menandatangani pernyataan kesediaan mengikuti syarat dan ketentuan perlindungan saksi dan korban
} 
1) Saksi dan/atau korban meminta agar perlindungan terhadapnya dihentikan dalam hal permohonan diajukan atas inisiatif sendiri;

2) atas permintaan pejabat yang berwenang dalam hal permintaan perlindungan terhadap saksi dan/atau korban berdasarkan atas permintaan pejabat yang bersangkutan;

3) Saksi dan/atau korban melanggar ketentuan sebagaimana tertulis dalam perjanjian; atau

4) Lembaga Perlindungan Saksi dan Korban berpendapat bahwa saksi dan/atau korban tidak lagi memerlukan perlindungan berdasarkan bukti-bukti yang meyakinkan.

Penghentian perlindungan keamanan seorang saksi dan/atau korban harus dilakukan secara tertulis. Undang-undang Perlindungan Saksi dan Korban juga mengatur mengenai bantuan bagi saksi atau korban sebagaimana diatur dalam Pasal 33 sampai dengan Pasal 36 sebagaimana penulis jelaskan sebagai berikut ini. Bantuan diberikan kepada seorang saksi dan/atau korban atas permintaan tertulis dari yang bersangkutan ataupun orang yang mewakilinya kepada Lembaga Perlindungan Saksi dan Korban dan menentukan kelayakan diberikannya bantuan kepada saksi dan/atau korban.

\section{d) Lembaga perlindungan saksi dan korban}

Undang-undang Perlindungan Saksi dan Korban ini juga melahirkan lembaga baru sebagimana ditentukan dalam Pasal 1 angka 3 yaitu Lembaga Perlindungan Saksi dan Korban yang merupakan lembaga yang bertugas dan berwenang untuk memberikan perlindungan dan hak-hak lain kepada saksi dan/atau korban sebagaimana diatur dalam Undang--undang ini. Lembaga Perlindungan Saksi dan Korban, merupakan lembaga yang mandiri dalam arti lembaga yang independent, tanpa campur tangan dari pihak manapun. Lembaga Perlindungan Saksi dan Korban juga berkedudukan di Ibu kota Negara Republik Indonesia dan mempunyai perwakilan di daerah sesuai dengan keperluan ${ }^{15}$.

\footnotetext{
${ }^{15}$ Lembaga Perlindungan Saksi dan Korban bertanggung jawab untuk menangani pemberian perlindungan dan bantuan pada saksi dan korban berdasarkan tugas dan kewenangannya, dan bertanggung jawab kepada Presiden. Lembaga Perlindungan Saksi dan Korban membuat laporan secara berkala tentang pelaksanaan tugas Lembaga Perlindungan Saksi dan Korban kepada Dewan
}

Anggota Lembaga Perlindungan Saksi dan Korban terdiri atas 7 (tujuh) orang yang berasal dari unsur profesional yang mempunyai pengalaman di bidang pemajuan, pemenuhan, perlindungan, penegakan hukum dan hak asasi manusia, kepolisian, kejaksaan, Departemen Hukum dan Hak Asasi Manusia, akademisi, advokat, atau lembaga swadaya masyarakat. Masa jabatan anggota Lembaga Perlindungan Saksi dan Korban adalah 5 (lima) tahun. Setelah berakhir masa jabatan, anggota Lembaga Perlindungan Saksi dan Korban dapat dipilih kembali dalam jabatan yang sama, hanya untuk 1 (satu) kali masa jabatan berikutnya.

Lembaga Perlindungan Saksi dan Korban terdiri atas Pimpinan dan Anggota, Pimpinan Lembaga Perlindungan Saksi dan Korban terdiri atas Ketua dan Wakil Ketua yang merangkap anggota. Pimpinan Lembaga Perlindungan Saksi dan Korban dipilih dari dan oleh anggota Lembaga Perlindungan Saksi dan Korban, ketentuan lebih lanjut mengenai tata cara pemilihan Pimpinan Lembaga Perlindungan Saksi dan Korban diatur dengan Peraturan Lembaga Perlindungan Saksi dan Korban. Masa jabatan Ketua dan Wakil Ketua Lembaga Perlindungan Saksi dan Korban selama 5 (lima) tahun dan sesudahnya dapat dipilih kembali dalam jabatan yang sama, hanya untuk 1 (satu) kali masa jabatan berikutnya.

Dalam pelaksanaan tugasnya, Lembaga Perlindungan Saksi dan Korban dibantu oleh sebuah sekretariat yang bertugas memberikan pelayanan administrasi bagi kegiatan Lembaga Perlindungan Saksi dan Korban. Sekretariat Lembaga Perlindungan Saksi dan Korban dipimpin oleh seorang Sekretaris yang berasal dari Pegawai Negeri Sipil. Sekretaris diangkat dan diberhentikan oleh Menteri Sekretaris Negara. Ketentuan lebih lanjut mengenai kedudukan, susunan, organisasi, tugas, dan tanggung jawab sekretariat sebagaimana dimaksud pada ayat (1) diatur dengan Peraturan Presiden. Peraturan Presiden ditetapkan dalam waktu paling lambat 3 (tiga) bulan sejak Lembaga Perlindungan Saksi dan Korban terbentuk. Panitia seleksi terdiri atas 5 (lima) orang, dengan susunan sebagai berikut:

1). 2 (dua) orang berasal dari unsur pemerintah ; dan

Perwakilan Rakyat paling sedikit sekali dalam 1 (satu) tahun. 
2). 3 (tiga) orang berasal dari unsur
masyarakat.

Anggota panitia seleksi tidak dapat dicalonkan sebagai anggota Lembaga Perlindungan Saksi dan Korban. Susunan panitia seleksi, tata cara pelaksanaan seleksi, dan pemilihan calon anggota Lembaga Perlindungan Saksi dan Korban diatur dengan Peraturan Presiden. Panitia seleksi mengusulkan kepada Presiden sejumlah 21 (dua puluh satu) orang calon yang telah memenuhi persyaratan. Presiden memilih sebanyak 14 (empat belas) orang dari sejumlah calon untuk diajukan kepada Dewan Perwakilan Rakyat. Dewan Perwakilan Rakyat selanjutnya memilih dan menyetujui 7 (tujuh) orang. Dewan Perwakilan Rakyat memberikan persetujuan dalam jangka waktu paling lambat 30 (tiga puluh) hari terhitung sejak tanggal pengajuan calon anggota Lembaga Perlindungan Saksi dan Korban diterima. Dalam hal Dewan Perwakilan Rakyat tidak memberikan persetujuan terhadap seorang calon atau lebih yang diajukan oleh Presiden, dalam jangka waktu paling lambat 30 (tiga puluh) hari terhitung sejak tanggal diterimanya pengajuan calon anggota Lembaga Perlindungan Saksi dan Korban, Dewan Perwakilan Rakyat harus memberitahukan kepada Presiden disertai dengan alasan, dan Presiden mengajukan calon pengganti sebanyak 2 (dua) kali jumlah calon anggota yang tidak disetujui.

Dewan Perwakilan Rakyat wajib memberikan persetujuan terhadap calon pengganti dalam jangka waktu paling lambat 30 (tiga puluh) hari terhitung sejak tanggal pengajuan calon pengganti diterima. Presiden menetapkan anggota Lembaga Perlindungan Saksi dan Korban yang telah memperoleh persetujuan Dewan Perwakilan Rakyat, dalam jangka waktu paling lambat 30 (tiga puluh) hari terhitung sejak tanggal persetujuan diterima Presiden. Anggota Lembaga Perlindungan Saksi dan Korban diangkat oleh Presiden dengan persetujuan Dewan Perwakilan Rakyat. Untuk dapat diangkat menjadi anggota Lembaga Perlindungan Saksi dan Korban harus memenuhi syarat:

1) warga negara Indonesia;

2) sehat jasmani dan rohani;

3) tidak pernah dijatuhi pidana karena melakukan tindak pidana kejahatan yang ancaman pidananya paling singkat 5 (lima) tahun;
4) berusia paling rendah 40 (empat puluh) tahun dan paling tinggi 65 (enam puluh lima) tahun pada saat proses pemilihan;

5) berpendidikan paling rendah S 1 (strata satu);

6) berpengalaman di bidang hukum dan hak asasi manusia paling singkat 10 (sepuluh) tahun;

7) memiliki integritas dan kepribadian yang tidak tercela; dan

8) memiliki nomor pokok wajib pajak.

Anggota Lembaga Perlindungan Saksi dan Korban diberhentikan karena:

1) meninggal dunia;

2) masa tugasnya telah berakhir;

3) atas permintaan sendiri;

4) sakit jasmani atau rohani yang mengakibatkan tidak dapat menjalankan tugas selama 30 (tiga puluh) hari secara terus menerus;

5) melakukan perbuatan tercela dan/atau halhal lain yang berdasarkan Keputusan Lembaga Perlindungan Saksi dan Korban yang bersangkutan harus diberhentikan karena telah mencemarkan martabat dan reputasi, dan/atau mengurangi kemandirian dan kredibilitas Lembaga Perlindungan Saksi dan Korban; atau

6) dipidana karena bersalah melakukan tindak pidana kejahatan yang ancaman pidananya paling singkat 5 (lima) tahun.

Ketentuan lebih lanjut mengenai tata cara pengangkatan dan pemberhentian anggota Lembaga Perlindungan Saksi dan Korban diatur dengan Peraturan Presiden. Keputusan Lembaga Perlindungan Saksi dan Korban diambil berdasarkan musyawarah untuk mufakat, dalam hal keputusan tidak dapat dicapai, keputusan diambil dengan suara terbanyak. Biaya yang diperlukan untuk pelaksanaan tugas Lembaga Perlindungan Saksi dan Korban dibebankan kepada Anggaran Pendapatan dan Belanja Negara.

\section{e) Perlindungan saksi dalam proses Penyidikan Perkara Pidana}

Dasar perlindungan Saksi dan/atau korban dalam proses penyidikan adalah Undang-undang tentang perlindungan saksi dan korban yaitu Undang-undang Nomor 13 Tahun 2006. yang menjadi salah satu payung hukum untuk memberikan perlindungan hukum bagi saksi dan korban. 
Dalam Praktek perlindungan saksi dan korban dalam proses penyidikan perkara adalah dengan cara melindungi saksi selama proses penyidikan dari ancaman-ancaman yang mungkin membahayakan saksi dan korban. Selama proses penyidikan keselamatan saksi ada di bawah lindungan pihak kepolisian. Perlindungan terhadap saksi dan korban harus diberikan bila menginginkan proses hukum berjalan benar dan keadilan ditegakkan.

\section{f) Kendala-kendala dalam Perlindungan hukum bagi saksi dalam proses penyidikan Perkara Pidana}

Dalam proses penyidikan perkara pidana yang dilakukan penyidik kepolisian, terkadang saksi akan menjadi tidak terlindungi hak-haknya dalam perannya dalam mengungkap fakta-fakta tindak pidana. Hal ini terjadi karena pernyataan pikiran yang tidak bebas karena merasa berada dibawah ancaman, dan sebabsebab lain yang dapat menimbulkan keterangan saksi menjadi beda dengan apa yang dilihat, didengar dan dialaminya.

Beberapa kendala dalam perlindungan hukum bagi saksi dan korban dalam proses penyidikan perkara tindak pidana adalah saksi dan korban merasa di bawah ancaman, melihat kasus bila kasus besar seperti pembunuhan maka saksi merasa terancam dan takut memberikan kesaksian, tidak maunya saksi memberikan kesaksian dan banyaknya tekanantekanan dari pihak lain dalam proses penyidikan. Hal ini disebabkan oleh beberapa faktor sebagai berikut :

1. Masih rendahnya tingkat pendidikan

\section{Faktor ekonomi}

3. Rasa takut bertemu dengan penyidik atau Polisi

4. Tidak mengetahui adanya Undang-undang perlindungan saksi

5. Adanya ancaman, baik fisik maupun psikis dari pihak tertentu

Perlindungan bagi saksi dan/atau korban yang sangat penting keberadaannya dalam proses penyidikan perkara pidana. Kesaksian memang dibutuhkan dalam setiap proses peradilan pidana, termasuk peradilan militer. Saksi yang dimintai keterangan dalam penyidikan maupun persidangan, pada dasarnya sangat membantu berjalannya rangkaian proses peradilan. g) Cara Mengatasi kendala-kendala dalam Perlindungan hukum bagi saksi dan korban dalam proses penyidikan perkara Pidana

Dari beberapa kendala tersebut diatas dalam upaya penyidikan perkara tindak pidana oleh penyidik kepolisian, maka diperlukan beberapa cara untuk mengatasi kendala tersebut dalam rangka melaksanakan perlindungan saksi dan korban kejahatan dengan memberikan penyuluhan kepada masyarakat guna memberikan informasi bahwa sudah adanya Undang-undang yang mengatur perlindungan saksi pada proses penyidikan yang dapat melindungi saksi dalam memberikan keterangan kepada pihak penyidik. Sehingga saksi dan korban tidak perlu lagi merasa dirinya terancam atau takut terhadap ancaman dari pihak luar karena sudah jelas selama proses penyidikan saksi dan korban dibawah lindungan pihak yang berwajib.

Untuk mengatasi kendala dalam menghadirkan saksi Penyidik juga mensosialisasikan bahwa saksi dan/atau korban yang tidak bersedia datang atau berhalangan untuk memberikan kesaksian dalam proses penyidikan diberikan kompensasi dan restitusi yang diatur dengan Peraturan Pemerintah. Perlindungan dan hak saksi dan korban diberikan sejak tahap penyelidikan dimulai dan berakhir. Saksi dan/atau korban yang merasa dirinya berada dalam ancaman yang sangat besar, atas persetujuan hakim dapat memberikan kesaksian tanpa hadir langsung di pengadilan tempat perkara tersebut sedang diperiksa. Saksi dan/atau korban dapat memberikan kesaksiannya secara tertulis yang disampaikan di hadapan pejabat yang berwenang dan membubuhkan tanda tangannya Pada berita acara pemeriksaan (BAP) saksi. Saksi dan/atau korban dapat pula didengar kesaksiannya secara langsung melalui sarana elektronik dengan didampingi oleh pejabat yang berwenang. Saksi, korban, dan pelapor tidak dapat dituntut secara hukum baik pidana maupun perdata atas laporan, kesaksian yang akan, sedang, atau telah diberikannya.

\section{KESIMPULAN}

Keinginan masyarakat Indonesia terhadap perlindungan saksi dan korban kejahatan dalam setiap proses perkara pidana, seakan-akan sudah teratasi dengan disahkannya Undang-undang Nomor 13 Tahun 2006 tentang Perlindungan Saksi dan Korban. Namun dalam 
mengimplementasikan keinginan terhadap perlindungan saksi dan korban dalam Undangundang Nomor 13 Tahun 2006 tentang Perlindungan Saksi dan Korban tidaklah hanya menjadi isapan jempol belaka saja, karena dalam konteks penyelidikan perkara pidana masih terbentur dengan doktrin yang di introdusir KUHAP, dengan menitikberatkan pada "nilai pembuktian" berbeda dengan pengaturan tentang orang-orang yang dapat dilindungi oleh Lembaga Perlindungan Saksi dan korban dalam Undang-undang Nomor 13 Tahun 2006 tentang Perlindungan Saksi dan Korban.

\section{SARAN}

Revisi Kuhap, terkait dengan peranan saksi dan korban dalam proses perkara pidana tentang "nilai Pembuktian" sehingga menjadi selaras dengan roh Undang-undang Nomor 13 Tahun 2006 tentang Perlindungan Saksi dan Korban

\section{SUMBER REFRENSI}

Arif Gosita, Masalah Korban Kejahatan, Akademika Pressindo, Jakarta, 1985.

Didik M. Arif Mansur, Urgensi Perlindungan Korban Kejahatan. Hugo Reading, Kamus Ilmu-ilmu social, Rajawali, Jakarta, 1986.
J.E. Sahetapy, Teori Kriminologi Suatu Pengantar, Citra Aditya Bakti, Bandung, 1992

Nyoman Serikat Putra Jaya, Sistem Peradilan Pidana (Criminal Justice Sistem), (Bahan Kuliah Program Magister Ilmu Hukum Universitas Diponegoro ,Semarang: 2006)

Surastini Fitriasih, "Perlindungan Saksi Dan Korban Sebagai Sarana Menuju Proses Peradilan (Pidana) Yang Jujur Dan Adil”, http/www.antikorupsi.org/mod=tema\& $\mathrm{op}=$ viewarticle \&artid $=53$

Asian Human Rights Commission Indonesia: Sebuah Tinjauan Kritis Mengenai Undang-Undang Perlindungan Saksi Dan Korban, http://indonesia.ahrchk.net/news/mainf ile.php/stbahasa/91/ Koalisi Perlindungan Saksi, Perlindungan Saksi Alas Tlogo Jakarta, 9 Januari 2007 Sabtu, 09 Juni 2007

UU No. 13 Tahun 2006 LPSK tidak mengatur perlindungan terhadap saksi dan korban secara spesifik. Sangat tergantung pada anggota Lembaga Perlindungan Saksi dan Korban",http://hukumonline.com/detail .asp? $\mathrm{id}=17767 \& \mathrm{cl}=$ Berita $-49 \mathrm{k}$ 